\title{
Growth Kinetics of Nanofrustulum Shiloi Under Different Mixing Conditions in Flat-plate Photobioreactor
}

\section{Zeliha Demirel ${ }^{1^{*}}$}

https://orcid.org/0000-0003-3675-7315

\section{Esra Imamoglu 1}

https://orcid.org/0000-0001-8759-7388

\section{Meltem Conk Dalay ${ }^{1}$}

https://orcid.org/0000-0002-1718-7292

${ }^{1}$ Ege University, Faculty of Engineering, Department of Bioengineering, Izmir, Turkey

Received: 2019.04.01; Accepted: 2020.02.13.

*Correspondence: zelihademirel@gmail.com; Tel.: +90-232-3115844

\section{HIGHLIGHTS}

- Growth and lipid profile determined using both aeration and mixing conditions.

- Higher lipid productivity found in PBR using only bubbling system.

- Fatty acids increased in PBR using the combination of bubbling and stirring system.

\begin{abstract}
Diatoms are the major group of microalgae which have been utilized by the potential applications as food industries, aquatic feeds, cosmetics, biofuels, and pharmaceuticals. In this study, current approaches were made in order to determine growth rate, biomass productivity, protein, carbohydrate, lipid and fatty acid composition for Nanofrustulum shiloi cultures using both aeration and mixing conditions in flat-plate photobioreactor (PBR). Physical (the intensity of aeration, mixing, light intensity etc.) and chemical (nutritional materials) factors are affecting the growth and bioproduct contents of a diatom. Biomass and lipid productivities of $N$. shiloi were measured as 31.29 and $36.9622 \pm 0.0598 \mathrm{mg} \mathrm{L}^{-1}$ day $^{-1}$ in flat-plate PBR having the combination of aeration and stirring system, respectively. A slightly higher amount of saturated fatty acids was detected in PBR having only bubbling system while the increase of mono- and poly- unsaturated fatty acids were found in PBR having the combination of aeration and stirring system. Flat-plate PBR design was also investigated for improving not only biomass but also the lipid productivity of $N$. shiloi.
\end{abstract}

Keywords: biochemical concentration; diatom; fatty acid profiles; flat-plate photobioreactor; Nanofrustulum shiloi 


\section{GRAPHICAL ABSTRACT}

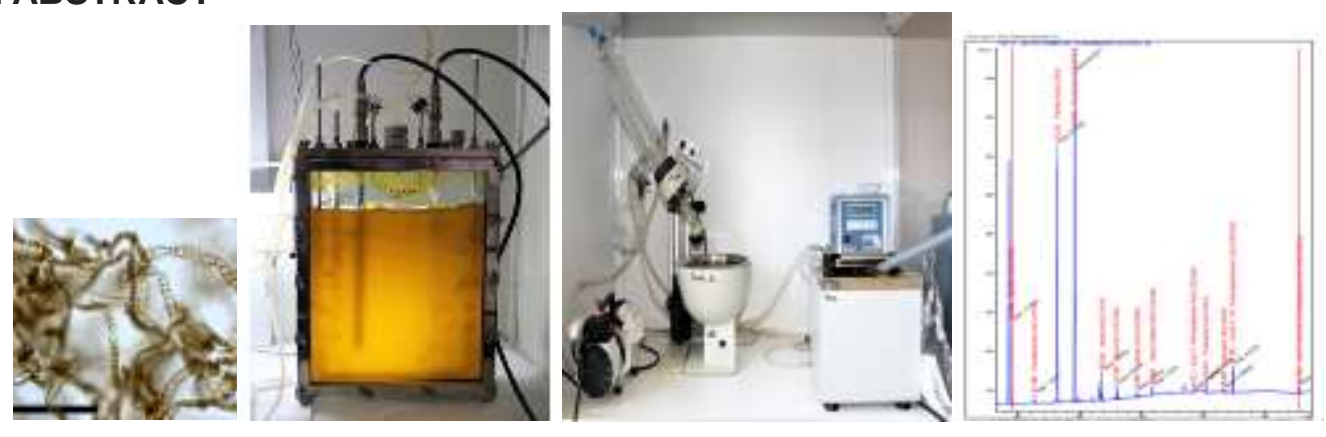

\section{INTRODUCTION}

Microalgae have been produced for a human and animal consumption as high valuable chemicals [1]. The fresh and marine microalgae biomass provides rich sources of protein, fatty acids, polysaccharides, carotenoids, amino acids [2], which has an encouraging future in food, feed, medicine and biotechnological applications.

Light intensity, mixing, temperature, $\mathrm{CO}_{2}$, dissolved oxygen, nutrient supply, and $\mathrm{pH}$ are the most important growth factors of algae. The two different systems of microalgae cultivation can be performed in open (raceway ponds, tank and pond) and closed systems (bubble columns, airlift, flat-plate, stirred tank, tubular, conical, and torus photobioreactors-PBR) [3]. Open systems are low capital and cost efficient but bring about various problems such as very low cell concentration, low mass productivity, contamination, susceptibility to climate as rain, and increases rate of vaporization. On the contrary, PBR provides an enclosed growing condition for algae growth parameters such as light distribution, light intensity, temperature, mixing, mass transfer and $\mathrm{pH}$. PBR design of geometry is to get an efficient availability of light. Apart from light, the hydrodynamics perform the most important operations in the development of a PBR. A gassed fluid transfer depends to bubbling size as well as liquid circulation velocity is important bioprocessing parameters. Mixing is also one of the most important roles in PBR performance such as eliminating gradients of concentration, temperature and other properties. Mixing can not only enhance biomass productivity in fluid by enhancing mass transfer, ensuring light intensity distribution, sufficient $\mathrm{CO}_{2}$ transfer and maintaining uniform $\mathrm{pH}$ but also prevent sedimentation in a PBR [4-7].

Flat-plate PBR provides a large illumination surface area due to their provided from either one or both sides of the reactor. The PBR has the advantage that it can be lower power consumption, high mass transfer capacity and long lifespan when compared the closed system PBRs. Challenges of PBR including possible damage to cells based on high light intensities can be caused photo-inhibition and can be also difficult to control of aeration in the system [4-8].

The aim of this study is to investigate the only bubbling system and the combination of bubbling and stirring system using a magnetic stirrer in a flat-plate photobioreactor for the increase of biomass productivity, protein, total sugar, lipid concentration and fatty acids components of Nanofrustulum shiloi.

\section{MATERIAL AND METHODS}

\section{Morphological observations and molecular identification}

Benthic diatom was isolated from Aegean Sea in Turkey and identified by morphological characteristics on the basis of observations under bright field (Olympus BX53, Japan 60X) and by scanning electron microscopy (SEM- Philips XL-30S FEG). For DNA extraction, the cultured strain (500 $\mu \mathrm{L})$ was harvested by centrifugation at 10,000 $\times g$ for 2 min and the cell pellet was used in the DNA Kits (Zymo Research) and stored at $-20^{\circ} \mathrm{C}$. PCR primers targeted to link $18 \mathrm{~S}$ rDNA (AT-F, 5'-YACCTGGTTGATCCTGCCAGTAG-3' and ATR, 5'-GCTTGATCCTTCTGCAGGTTCACC-3'). PCR protocol was performed with the following conditions: $94^{\circ} \mathrm{C}$ for $2 \mathrm{~min}$, following 35 cycles of $94^{\circ} \mathrm{C}$ for $20 \mathrm{~s}, 55^{\circ} \mathrm{C}$ for $30 \mathrm{~s}$, and $72{ }^{\circ} \mathrm{C}$ for $2 \mathrm{~min}$, and a final extension at $72^{\circ} \mathrm{C}$ for $5 \mathrm{~min}$. PCR products were viewed in an agarose gel with stained under a UV light. In the DNA sequencing step, dye-terminator sequencing was done using the primers and the nucleotide chromatograms were determined by DNA sequencer (Applied Biosystems 3130XL).

The sequences obtained in this study were deposited in NCBI GenBank and the accession numbers of KR149459. 
Nanofrustulum shiloi (J.J.Lee, Reimer \& McEnery) Round, Hallsteinsen \& Paasche (EGEMACC 47) was added in the Microalgae Culture Collection of Ege University, Izmir-Turkey (http://www.egemacc.com) for safe storage The sample was grown in aired sterile bottle $(1 \mathrm{~L})$, containing $900 \mathrm{~mL}$ of BG-11 medium including $20 \mathrm{~g} / \mathrm{L}$ sea salt at $20 \pm 2{ }^{\circ} \mathrm{C}$ under the continuous light supplied by cool-white fluorescent. The cells were used as inoculant with the concentration of $10 \%(\mathrm{v} / \mathrm{v})$ for flat-plate photobioreactors experiments.

\section{Flat-plate photobioreactor design}

The characterization of a $7 \mathrm{~L}$ flat- plate PBR composed of Plexiglas enclosed in a rigid metal frame with the dimension of $0.34 \mathrm{~m}$ height, $0.145 \mathrm{~m}$ length and $0.082 \mathrm{~m}$ width with a working volume of $6 \mathrm{~L}$ was equipped with an online controller (Biosis, Pikolab, Turkey). A temperature-dissolved oxygen probes and $\mathrm{pH}$ probe were located in the upper part of the PBR. The culture $\mathrm{pH}$ and dissolved oxygen was measured by a sensor and the temperature was maintained at $22 \pm 2{ }^{\circ} \mathrm{C}$ in the temperature-controlled incubator. Additionally, the ratio of illuminated surface area to reactor volume of the flat-plate PBR was calculated as $12.19 \mathrm{~m}^{-1}$ [9]. PBR made of stainless steel was autoclaved at $121^{\circ} \mathrm{C}$ for $15 \mathrm{~min}$ prior to use. Two different mixing systems were used in flat-plate. In the first PBR, only air bubbling- $U$ type aeration system (Figure 1A) was used with the aeration rate of $4 \mathrm{~L} \mathrm{~min}{ }^{-1}$ controlled using flow meter (RST electronic Ltd, LZM-6T Turkey). The other PBR was used both air bubbling- $L$ type aeration system and magnetic stirrer (IKA) (Figure 1B) with the aeration rate of $4 \mathrm{~L} \mathrm{~min}{ }^{-1}$ at a mixing rate of $150 \mathrm{rpm}$. Illumination was provided under a 16:8 $\mathrm{h}$ light:dark cycle on the frontal plate by light emitting diodes lamp (LED-Cata 10W CT-5254) with a light intensity of $50 \mu$ mol photons $\mathrm{m}^{-2} \mathrm{~s}^{-1}$.

$\mathrm{K}_{\mathrm{L}} \mathrm{a}$, the final steady dissolved oxygen concentration $\check{C}_{\mathrm{L}}$, can be estimated using two points from several values of $\left(\mathrm{CA}_{\mathrm{L} 1}, t_{1}\right)$ and $\left(\mathrm{CA}_{\mathrm{L} 2}, t_{2}\right)$. When $\operatorname{In}(\check{\mathrm{C} A L}-\mathrm{CAL} 1 / \check{\mathrm{C} A L}-\mathrm{CAL2})$ is plotted against $\left(t_{2-} t_{1}\right)$, the slope is KLa.

A

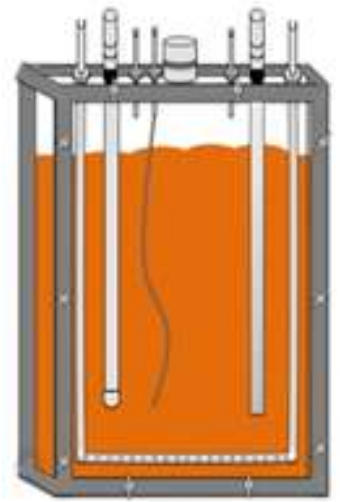

B

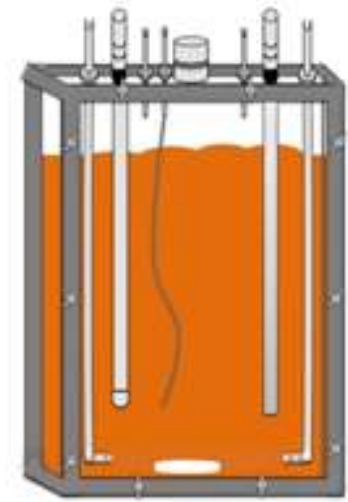

Figure 1. Schematic diagram of bioreactor geometries used for phototrophic diatom cultivation A: air bubbling system (U-type airing), B: combination of air bubbling and stirring system (L-type airing)

\section{Analytic procedure}

Samples were taken at two days intervals in the batch culture period of 20 days and the following growth parameters (the cell number, turbidity, chlorophyll-a, -c and fucoxanthin concentration) were measured.

The cell concentration was determined by counting duplicate samples in a Neubauer hemocytometer. Dry weight was determined in duplicate by filtering a $5-\mathrm{mL}$ culture sample through preweighed filters (Macherey-Nagel MN GF-3) and weighed after drying the cell mass at $65^{\circ} \mathrm{C}$ for overnight. The optical density of the culture was evaluated by using a spectrophotometer (Ultraspec 1100 pro, Amersham), at $\lambda=600$ and $680 \mathrm{~nm}$.

The specific growth rate $(\mu)$ of the cells was calculated from the initial logarithmic phase of growth for at least $72 \mathrm{~h}$, as $\mu=(\ln X 2-\ln X 1) / d t$, where $X 2$ is the final cell concentration, $X 1$ is the initial cell concentration and $\mathrm{dt}$ is the time required for the increase in concentration from $\mathrm{X} 1$ to $\mathrm{X} 2$. Doubling time (Dt) was also calculated as $\mathrm{Dt}=\ln 2 / \mu$.

For the chlorophyll-a, -c and fucoxanthin measurement, cells were harvested at $5500 \mathrm{rpm}$ for $5 \mathrm{~min}$. Pigments in the cells was extracted with aceton:methanol: $\mathrm{H}_{2} \mathrm{O}(3: 1: 1)$ for 30 min at $30^{\circ} \mathrm{C}$ in sonic bath (Hydra, Ultrasonic, Turkey) under total darkness. The amount of chlorophyll-a (Equation 1), -c (Equation 2) and fucoxanthin (Equation 3) was determined spectrophotometrically by measuring the light absorption at 
different wavelengths $(664,631,581$, and $470 \mathrm{~nm})$ [10]. The pigment contents were calculated by using the following equation:

$$
\begin{aligned}
& \text { Chlorophyll } a=A_{664} / 73.6 \\
& \text { Chlorophyll } c=\left(A_{631}+A_{581}-0.3 A_{664}\right) / 62.2 \\
& \text { Fucoxanthin }=\left(A_{470}-1.239\left(A_{631}+A_{581}-0.3 A_{664}\right)-0.0275 A_{664}\right) / 141
\end{aligned}
$$

Total lipid was extracted by a modified method of Bligh and Dyer which is reported in Sahin and coauthors [11]. The carbohydrate and protein contents of $N$. shiloi cells were determined by the phenol-sulfuric acid [12] and modified Lowry methods [13], respectively. Fatty acids composition were analyzed by GC-FID (Typical Agilent 6890 GC Gas Chromatograph FID System) using the Turkish standard methods TS EN ISO 129662:2017 and TS EN ISO 12966-4:2015.

Results from tracing duplicate samples are presented in figures and tables, and the data for each experiment were averaged. The experimental data were analyzed by one-way ANOVA. A probability of $p$-value is less than 0.05 level was considered to outcome a statistically significant.

\section{RESULTS AND DISCUSSION}

Photobioreactor (PBR) has to be considerable reactor types for the biomass cultivation of photosynthetic microalgae. The flat-panel PBR owns a lot of good properties such as a high ratio of illuminated surface area to reactor volume, temperature control, low energy consumption, a high gassed liquid transfer rate and high photosynthetic efficient [5-8]. In this study, only bubbling system and both magnetic stirring and bubbling system in flat-plate PBR was investigated for benthic diatoms, Nanofrustulum shiloi, isolated from the sea sand of Aegean Sea in Izmir-Turkey.

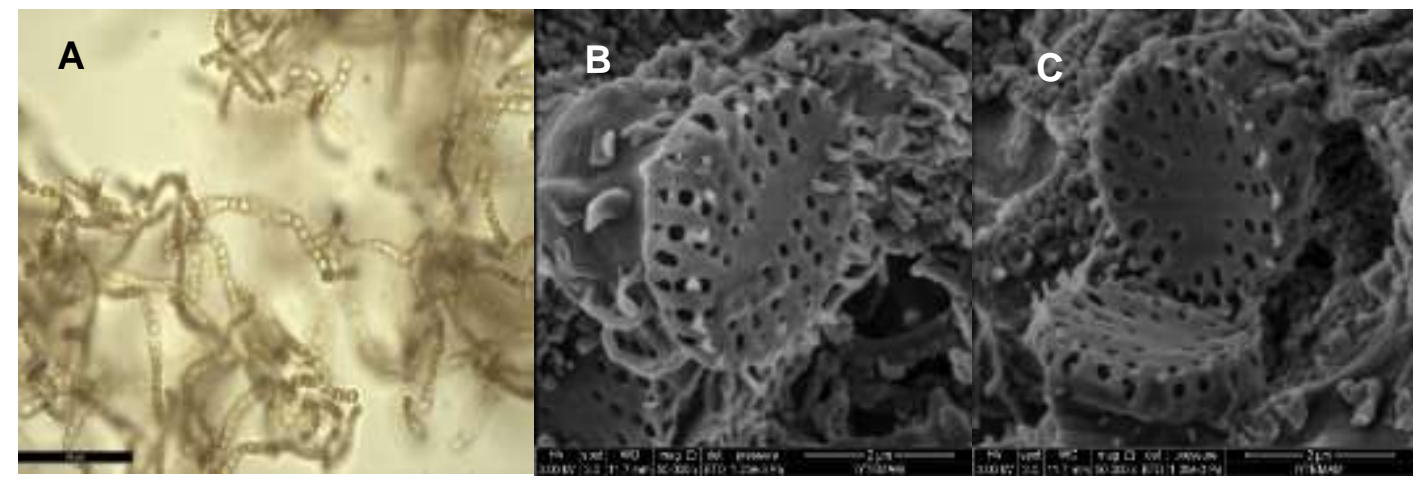

Figure 2. Light microscopy observation (63 x magnification) for $N$. shiloi (A) and identification of diatom with SEM image (50000x) (B-C)

Nanofrustulum shiloi (J.J.Lee, Reimer \& McEnery) Round, Hallsteinsen \& Paasche Figure 1; N. shiloi is not easy to identify under light microscopy based on due to its tiny oval valve for many araphid diatoms [14]. As seen in Figure $2 \mathrm{~A}$, Cells unit in short chains, bound with interlocking marginal head spines. Valves are circular to partially oval nearly 2.7-3.9 $\mu \mathrm{m}$ diameter. Valve surface flat is mantle curved or vertical. Frustules are rectangular, forming chains linked by interlocking marginal spines. The valves observed were circular, as are centric diatoms, but with the sternum central (SEM Figure) or slightly eccentric (Figure 2 B-C). Marginal head spines were contained peripherally across the rows of areolae (Figure $2 \mathrm{~B}-\mathrm{C}$ ).

In general, the advantages of flat-plate PBR are high biomass productivity and uniform distribution of light on the plate side. Aeration rate is a major parameter that improving the growth of microalgal cells. Gas aeration is supplied to the cell growth and to control of $\mathrm{pH}$, reduce nutrients gradient in the medium, avoid cell sedimentation, emergence of dead zones, clumping of cells, and fouling in the PBR, as well as increase the photosynthesis [15]. However, high liquid velocities and turbulence of too much mixing may be produce damage of shear-selective cells $[16,17]$.

$N$. shiloi comprised of shorter chain forms in the combination of bubbling and stirring system of PBR (L type airing) but rigid long chain forms produced in only bubbling system of flat-plate PBR (U type airing). Fragmentation cells of short chain diatom increased cell number while decreased specific growth rate in $U$ type aeration reactor, as shown in Table 1, Figure 3A. Because fragmentation of chain diatoms is intrinsically sink faster than elongation of chain diatoms. PBR having the combination of air bubbling and stirring system reached the highest specific growth rate $\left(0.4573\right.$ day $\left.^{-1}\right)$ with the biomass productivity of $31.29 \mathrm{mg} \mathrm{L}^{-1}$ day $^{-1}$ 
due to the increase of the volumetric mass transfer coefficient $\left(\mathrm{K}_{\mathrm{L}} \mathrm{a}\right)$ enhanced photosynthesis especially for chlorophyll-a (1.3179 $\left.\pm 0.0136 \mathrm{mg} \mathrm{L}^{-1}\right)$ and fucoxanthin concentration $\left(23.0263 \pm 0.0124 \mathrm{mg} \mathrm{L}^{-1}\right)($ Table 2). Furthermore, chain length affects the sinking rate of diatoms so as to longer chain stand buoyancy for longer times in the light absorption and nutrient uptake [18]. Takabayashi and coauthors [19] reported that the sinking rate of long chain forming diatom Skeletonema costatum was related to suspended in upper water column and so likely achieve the chemical and physical conditions for growth. However, chain formation may be important for biotechnological applications due to the simple collection of biomass in bioreactors. Thanks to the manipulation of chain form in photobioreactor could enhance biomass gathering and easily separation form the medium using sedimentation.

A

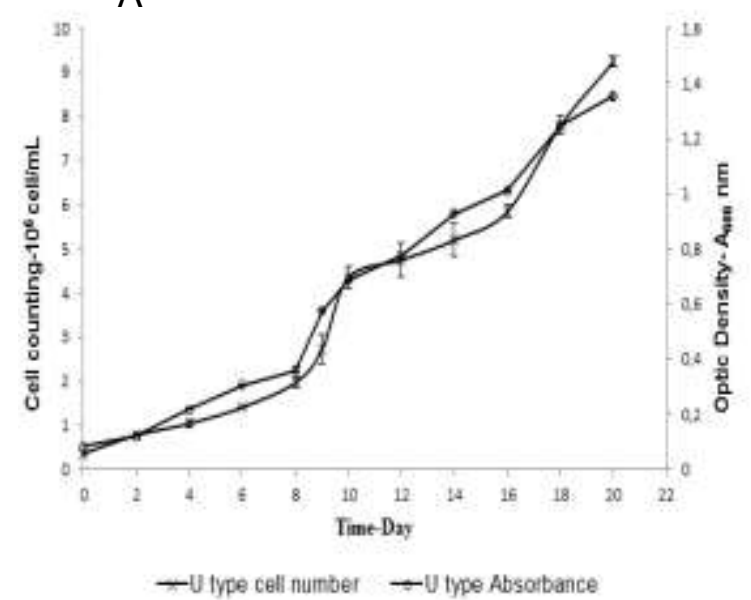

B

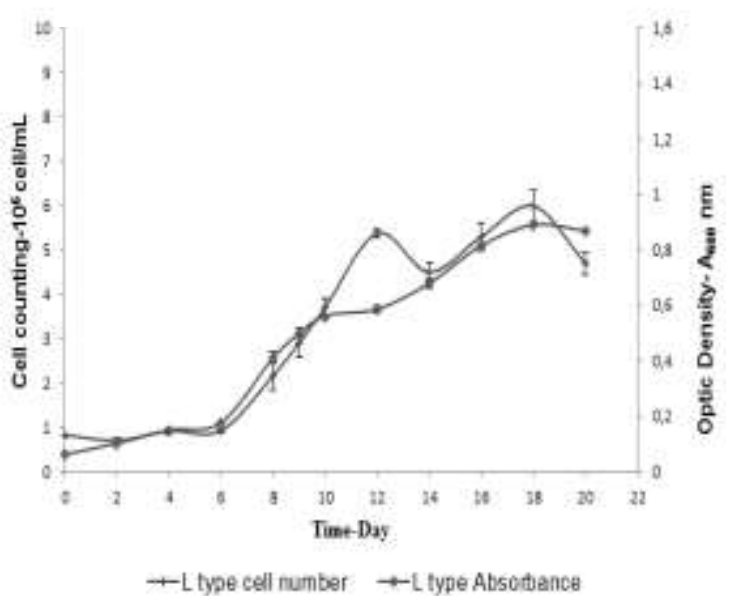

Figure 3. Optic density and cell number of $N$. shiloi growth in flat-plate PBR using $U$ (only bubbling)-A and $L$ type airing (combination of bubbling and stirring)-B

Table 1. Specific growth rate, doubling time and biomass productivity of Nanofrustulum shiloi

\begin{tabular}{lcccc}
\hline & $\begin{array}{c}\mathbf{K}_{\mathbf{L}} \mathbf{a} \\
\left(\mathbf{s}^{-1}\right)\end{array}$ & $\begin{array}{c}\text { Specific growth } \\
\text { rate }\left(\text { day }^{-1}\right)\end{array}$ & $\begin{array}{c}\text { Doubling time } \\
(\text { day })\end{array}$ & $\begin{array}{c}\text { Biomass productivity } \\
\left(\text { mg L }^{-1} \text { day }^{-1}\right)\end{array}$ \\
\hline $\begin{array}{l}U \\
\text { L type airing (only bubbling) }\end{array}$ & 0.0078 & 0.2816 & 2.4620 & 19.095 \\
bubbe airing (combination of & 0.0194 & 0.4573 & 1.5157 & 31.29 \\
\hline
\end{tabular}

$N$. shiloi was selected microorganism because of its explicit fast growth and highest biomass amount in culture, generally considered as feed to aquatic animals. Kiron, 2012 stated that about general composition of Nanofrustulum evaluated to include ash 530.7, protein 118.9, lipid 31.4, moisture 31.5 (dry weight, $\mathrm{g} \mathrm{kg}^{-1}$ ) for utilize in fishmeal for Atlantic salmon, common carp and whiteleg shrimp. Atlantic salmon can be tolerated at $17 \%$ of lipid-extracted Nanofrustulum mass in the diet [20,21]. Furthermore, Nuzzo and coauthors [22] reported that $N$. shiloi included significant level of sterol sulfates as brassicasterol sulfate (24 $\beta$-methyl-22dehydrocholesterol) $\left(5.94 \pm 1.0 \mu \mathrm{g} \mathrm{mg}^{-1}\right)$ and fucosterol sulfate (24-ethylidene cholesterol) $(60.69 \pm 7.3$

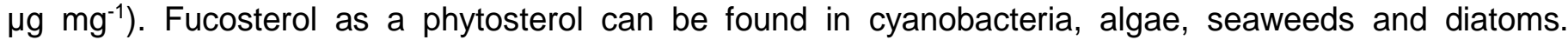
Fucosterol has various biological therapeutics activities such as anti-cancer, anti-diabetic, anti-oxidant, cholesterol lowering, blood vessel thrombosis preventive [23]. In this study, maximum lipid content was found as $26.3226 \pm 0.0357 \%$ dry cell biomass in flat-plate PBR (only bubbling system) using U type airing, whereas maximum lipid productivity was obtained in flat-plate PBR using $L$ type airing (combination of bubbling and stirring) in this study. The higher lipid productivity was attained in PBR having only bubbling system. At the end of the production the dry weight was obtained as $0.38 \mathrm{~g} \mathrm{~L}^{-1}$ and $0.6258 \mathrm{~g} \mathrm{~L}^{-1}$ in PBR having only bubbling system and having the combination of bubbling and stirring system, respectively. Effective mixing was achieved in PBR having the combination of bubbling and stirring system, therefore biomass productivity was higher than PBR having the only bubbling system. In this reason, lipid productivity per biomass has been detected higher in PBR having only bubbling system. Also, the highest $\mathrm{K}_{\mathrm{L}} \mathrm{a}$ of $0.0194 \mathrm{~s}^{-1}$ was found in PBR having the combination of bubbling and stirring system indicated that effective mixing is occurred. The lower mixing in PBR using $U$ type airing (only bubbling system) may be reduced the photosynthetic efficiency (0.8673 $\pm 0.0408 \mathrm{mg} \mathrm{L}^{-1}$ chlorophyll-a and $18.4070 \pm 0.1372 \mathrm{mg} \mathrm{L}^{-1}$ fucoxanthin concentration) (Table 2). 
Table 2. Maximum protein, carbohydrate and lipid concentration of Nanofrustulum shiloi

\begin{tabular}{lcc}
\hline & $\begin{array}{c}\text { U type airing } \\
\text { (only bubbling) }\end{array}$ & $\begin{array}{c}\text { L type airing (combination } \\
\text { of bubbling and stirring) }\end{array}$ \\
\hline $\begin{array}{l}\text { Max. protein concentration } \\
\left(\mathrm{mg} \mathrm{mL}^{-1}\right)\end{array}$ & $0.0858 \pm 0.0035$ & $0.2551 \pm 0.0037$ \\
$\begin{array}{l}\text { Max. carbohydrate } \\
\text { concentration } \\
\left(\mathrm{mg} \mathrm{mL}^{-1}\right)\end{array}$ & $0.1139 \pm 0.0039$ & $0.0831 \pm 0.0013$ \\
$\begin{array}{l}\text { Lipid content } \\
(\%) \text { dry cell biomass }\end{array}$ & $26.3226 \pm 0.0357$ & $23.6025 \pm 0.0490$ \\
$\begin{array}{l}\text { Total lipid productivity } \\
\left(\mathrm{mg} \mathrm{L}^{-1} \text { day }\right.\end{array}$ & $25.1312 \pm 0.0588$ & $36.9622 \pm 0.0598$ \\
$\begin{array}{l}\text { Max. chlorophyll-a } \\
\left(\mathrm{mg} \mathrm{L}^{-1}\right)\end{array}$ & $0.8673 \pm 0.0408$ & $1.3179 \pm 0.0136$ \\
$\begin{array}{l}\text { Max. fucoxanthin } \\
\left(\mathrm{mg} \mathrm{L}^{-1}\right)\end{array}$ & $18.4070 \pm 0.0137$ & $23.0263 \pm 0.0124$ \\
\hline
\end{tabular}

This was related to biomass formation during the cultivation. Generally, diatoms have been reported to have high contents of the myristic acid (C14:0), palmitic acid (C16:0), palmitoleic acid (C16:1) and eicosapentaenoic acid (C20:5), with only trace contents of $\mathrm{C} 18$ fatty acids [24, 25]. However, N. shiloi contained palmitic acid (C16:0); tricosanoic acid (C23:0); palmitoleic acid (C16:1) and cis-5,8,11,14,17eicosapentaenoic acid (C20:5) as major fatty acid profiles, while minor amount of arachidic acid (C20:0) and cis-13,16-docasadienoic acid (C22:2). In fatty acid components, diatoms are involved both short/middle-chain fatty acids and very long chain-polyunsaturated fatty acids. Middle chain fatty acids are preferred the biodiesel production for less viscous whereas long chain fatty acids as omega 3 fatty acids (eicosapentaenoic acid and docosahexaenoic acid) with application in pharmaceutical and nutraceutical industries [26,27]. Fatty acid composition is also shown to be highly variable by diatoms depending on the species and growth conditions such as chemical composition, light intensity and temperature fluctuate $[11,28,29]$. The lower growth rate found in PBR using U type airing led to higher proportion of saturated fatty acids, whereas the higher growth rate found in PBR using $L$ type airing resulted in higher fractions of unsaturated fatty acids. Furthermore, this work emphasized that the chain form composing diatoms was important effect for mixing and/or bubbling changes on lipid, protein and carbohydrate concentrations.

Table 3. Fatty acids profiles of Nanofrustulum shiloi $(n=1)$

\begin{tabular}{lcc}
\hline Fatty acids compositions & U type airing & L type airing \\
\hline Sum of Saturated (\%) & 45.178 & 41.791 \\
Myristic Acid (C14:0) & 1.387 & 1.420 \\
Pentadecanoic Acid (C15:0) & 0.649 & 0.560 \\
Palmitic Acid (C16:0) & 33.95 & 28.26 \\
Heptadecanoic Acid (C17:0) & 0.500 & 0.429 \\
Stearic Acid (C18:0) & 3.226 & 3.789 \\
Arachidic Acid (C20:0) & - & 0.089 \\
Behenic Acid (C22:0) & 0.888 & 0.957 \\
Tricosanoic Acid (C23:0) & 4.578 & 6.287 \\
Sum of Mono-unsaturated (\%) & 44.961 & 45.578 \\
Palmitoleic Acid (C16:1) & 41.46 & 41.93 \\
Trans Oleic Acid (C18:1n9t) & 2.574 & 2.769 \\
Erucic Acid (C22:1n9) & 0.819 & 0.793 \\
Nervonic Acid (C24:1) & 0.108 & 0.086 \\
Sum of Poly-unsaturated (\%) & 9.769 & 12.619 \\
Linoleic Acid (C18:2n6c) & 2.843 & 3.045 \\
Trans Linolenic Acid (C18:3n6) & 2.308 & 2.438 \\
cis-8,11,14-Eicosatrienoic Acid (C20:3n6) & 0.166 & 0.134 \\
cis-13,16-Docasadienoic Acid (C22:2) & 0.052 & 0.033 \\
cis-5,8,11,14,17-Eicosapentaenoic Acid (C20:5) & 4.400 & 6.969 \\
\hline
\end{tabular}

The sum of saturated (SFA), mono-unsaturated (MUFA) and poly-unsaturated fatty acids (PUFA) of $N$. shiloi cultivated in U type airing flat-plate PBR (only bubbling) were $45.178 \%, 44.961 \%$ and $9.769 \%$ of the total fatty acids whereas the values were $41.791 \%, 45.578 \%$ and $12.619 \%$, in L type airing flat-plate PBR 
(combination of bubbling and stirring), respectively. Sahin and coautohrs [11] reported that $N$. shiloi cultivated in $2 \mathrm{~L}$ sterile bottle at the temperature of $22 \pm 2{ }^{\circ} \mathrm{C}$ with the aeration of $2 \mathrm{~L} \mathrm{~min}-1$ was found in standard BG-11 with the SFA, MUFA and PUFA proportions of $64.79 \%, 29.85 \%$ and $5.35 \%$, respectively. In flat-plate PBR having the combination bubbling and stirring system, the content of unsaturated fatty acids was observed higher than in PBR having the only bubbling system.

\section{CONCLUSIONS}

The marine benthic diatom Nanofrustulum shiloi, was produced in a flat-plate photobioreactor for screening both aeration and mixing conditions included growth rate, lipid, protein and fatty acid composition. The results showed that the growth rate and fatty acid composition increased in PBR having the combination bubbling and stirring system. To further increase the lipid production, future investigations should focus on the augmentation of unsaturated fatty acids for utilization of these metabolites in medical, food, feed and biofuel industries. The results of this study have demonstrated that flat-plate photobioreactors could operate at high efficiency for diatom cultivation.

Funding: This research was funded by the European Seventh Framework Programme, grant number FP7-KBBE-20093- FP7-KBBE-2009-3.

Acknowledgments: This study was a part of the Novel Marine Bioactive Compounds for European Industries- MAREX project and the authors would like to thank for financial support.

Competing interests: The authors declare that they have no competing interests.

\section{REFERENCES}

1. Raja R, Coelho A, Hemaiswarya S, Kumar P, Carvalho IS, Alagarsamy A. Applications of microalgal paste and powder as food and feed: An update using text mining tool. BJBAS. 2018 Dec;7(4):740-7.

2. Sathasivam R, Radhakrishnan R, Hashem A, Abd_Allah EF. Microalgae metabolites: A rich source for food and medicine. Saudi J Biol Sci. 2019 May;26(4):709-22.

3. Bitog JP, Lee IB, Lee CG, Kim KS, Hwang HS, Hong SW, Seo IH, Kwon KS, Mostafa E. Application of computational fluid dynamics for modeling and designing photobioreactors for microalgae production: a review. Comput Electron Agric. 2011 May; 76(2):131-47.

4. Soman A, Shastri Y. Optimization of novel photobioreactor design using computational fluid dynamics. Appl Energ. 2015 Feb;140:246-55.

5. Huang Q, Jiang F, Wang L, Yang C. Design of photobioreactors for mass cultivation of photosynthetic organisms. Engineering. 2017 Jun;3(3):318-29.

6. Pires JC, Alvim-Ferraz MC, Martins FG. Photobioreactor design for microalgae production through computational fluid dynamics: a review. Renew Sust Energ Rev. 2017 Nov;79:248-54.

7. Hernández-Melchor DJ, Cañizares-Villanueva RO, Terán-Toledo JR, López-Pérez PA, Cristiani-Urbina E. Hydrodynamic and mass transfer characterization of flat-panel airlift photobioreactors for the cultivation of a photosynthetic microbial consortium. Biochem Eng J. 2017 Dec;128:141-8.

8. Dormido R, Sánchez J, Duro N, Dormido-Canto S, Guinaldo M, Dormido S. An interactive tool for outdoor computer controlled cultivation of microalgae in a tubular photobioreactor system. Sensors. 2014 Mar;14(3):4466-83.

9. Guler BA, Deniz I, Demirel Z, Oncel SS, Imamoglu E. Transition from start-up to scale-up for fucoxanthin production in flat plate photobioreactor. J Appl Phycol. 2019 Jun;31(3):1525-33.

10. Robertson, D. ALGAL pigments [Internet]-The Robertson Laboratory; [updated 2019 Mar 23; cited 2019 Dec 15]. Available from: https://wordpress.clarku.edu/debrobertson/laboratory-protocols/algal-pigments/

11. Sahin MS, Khazi MI, Demirel Z, Dalay MC. Variation in growth, fucoxanthin, fatty acids profile and lipid content of marine diatoms Nitzschia sp. and Nanofrustulum shiloi in response to nitrogen and iron. Biocatal Agric Biotechnol. 2019 Jan;17:390-8.

12. Tebiani M, Demirel Z, Imamoglu E, Dalay MC. Effects of sodium glyoxylate and light intensity on growths and exopolysaccharide productions of Prasinococcus sp. and Porphyridium cruentum. Fresen Environ Bull. 2015 May;24:1767-73.

13. Khazi MI, Demirel Z, Dalay MC. Evaluation of growth and phycobiliprotein composition of cyanobacteria isolates cultivated in different nitrogen sources. J. Appl Phycol. 2018 Jun; 30:1513-23.

14. Li CL, Witkowski A, Ashworth MP, Dąbek P, Sato S, Zgłobicka I, Witak M, Khim JS, Kwon CJ. The morphology and molecular phylogenetics of some marine diatom taxa within the Fragilariaceae, including twenty undescribed species and their relationship to Nanofrustulum, Opephora and Pseudostaurosira. Phytotaxa. 2018 Jun;355(1):1104. 
15. Anjos M, Fernandes BD, Vicente AA, Teixeira JA, Dragone G. Optimization of $\mathrm{CO}_{2}$ bio-mitigation by Chlorella vulgaris. Bioresour Technol. 2013 Jul;139:149-54.

16. Guo X, Yao L, Huang Q. Aeration and mass transfer optimization in a rectangular airlift loop photobioreactor for the production of microalgae. Bioresour Technol. 2015 Aug; 190:189-95.

17. Jacobi DB, Ivanova DI, Posten IC. Photobioreactors: Hydrodynamics and mass transfer. IFAC Proceedings Volumes. 2010; 43(6):162-7.

18. Svensson F, Norberg J, Snoeijs P. Diatom cell size, coloniality and motility: trade-offs between temperature, salinity and nutrient supply with climate change. PloS one. 2014 Oct 3;9(10):e109993.

19. Takabayashi M, Lew K, Johnson A, Marchi AL, Dugdale R, Wilkerson FP. The effect of nutrient availability and temperature on chain length of the diatom, Skeletonema costatum. J Plankton Res. 2006 Sep;28(9):831-40.

20. Kiron V, Phromkunthong W, Huntley M, Archibald I, De Scheemaker G. Marine microalgae from biorefinery as a potential feed protein source for Atlantic salmon, common carp and whiteleg shrimp. Aquacult Nutr. 2012 Apr;18(5):521-31.

21. Tibbetts SM. The Potential for 'Next-Generation', Microalgae-Based Feed Ingredients for Salmonid Aquaculture in Context of the Blue Revolution. In Microalgal Biotechnology. IntechOpen; 2018Jun. 151-75.

22. Nuzzo G, Gallo C, d'Ippolito G, Manzo E, Ruocco N, Russo E, Carotenuto Y, Costantini M, Zupo V, Sardo A, Fontana A. UPLC-MS/MS Identification of Sterol Sulfates in Marine Diatoms. Mar Drugs. 2019 Dec;17(1):10.

23. Abdul QA, Choi RJ, Jung HA, Choi JS. Health benefit of fucosterol from marine algae: a review. J Sci Food Agric. 2016 Apr;96(6):1856-66.

24. Demirel Z. Identification and Fatty Acid Composition of Coccolithophore and Diatom Species Isolated from Aegean Sea. Rom Biotech Lett. 2016 Jan;21(4):11747-53.

25. Zulu NN, Zienkiewicz K, Vollheyde K, Feussner I. Current trends to comprehend lipid metabolism in diatoms. Prog Lipid Res. 2018 Apr;70:1-16.

26. Marella ER, Holkenbrink C, Siewers V, Borodina I. Engineering microbial fatty acid metabolism for biofuels and biochemicals. Curr Opin Biotechnol. 2018 Apr;50:39-46.

27. Hamilton M, Powers S, Napier J, Sayanova O. Heterotrophic production of omega-3 long-chain polyunsaturated fatty acids by trophically converted marine diatom Phaeodactylum tricornutum. Mar Drugs. 2016 Mar; 14(3):53.

28. Stonik V, Stonik I. Low-molecular-weight metabolites from diatoms: structures, biological roles and biosynthesis. Mar Drugs. 2015 Jun; 13(6):3672-709.

29. Li HY, Lu Y, Zheng JW, Yang WD, Liu JS. Biochemical and genetic engineering of diatoms for polyunsaturated fatty acid biosynthesis. Mar Drugs. 2014 Jan; 12(1):153-66.

2020 by the authors. Submitted for possible open access publication under the terms and conditions of the Creative Commons Attribution (CC BY NC) license (https://creativecommons.org/licenses/by-nc/4.0/). 